\title{
Mendelian randomization analysis identified genes pleiotropically associated with central corneal thickness
}

Zhikun Yang ${ }^{1}$, Jingyun Yang ${ }^{2,3}, \mathrm{Di} \mathrm{Liu}^{4}$, Weihong $\mathrm{Yu}^{1}$

${ }^{1}$ Department of Ophthalmology, State Key Laboratory of Complex Severe and Rare

Diseases, Peking Union Medical College Hospital, Key Laboratory of Ocular Fundus

Diseases, Chinese Academy of Medical Sciences, Beijing, China

${ }^{2}$ Rush Alzheimer's Disease Center, Rush University Medical Center, Chicago, IL, USA

${ }^{3}$ Department of Neurological Sciences, Rush University Medical Center, Chicago, IL,

USA

${ }^{4}$ Beijing Key Laboratory of Clinical Epidemiology, School of Public Health, Capital

Medical University, Beijing, China

Corresponding to:

Weihong Yu

Department of Ophthalmology

State Key Laboratory of Complex Severe and Rare Diseases

Peking Union Medical College Hospital

Key Laboratory of Ocular Fundus Diseases

Chinese Academy of Medical Sciences

No.1 Shuaifuyuan Road

Dongcheng District, Beijing 100730

China 
medRxiv preprint doi: https://doi.org/10.1101/2021.02.27.21252574; this version posted March 2, 2021. The copyright holder for this preprint (which was not certified by peer review) is the author/funder, who has granted medRxiv a license to display the preprint in perpetuity.

All rights reserved. No reuse allowed without permission.

\section{Tel: 86-10-69156351}

Fax: 86-10-69156351

E-mail: yuweihongeye@foxmail.com 


\begin{abstract}
Objective: To prioritize genes that were pleiotropically or potentially causally associated with central corneal thickness (CCT).

Methods: We applied the summary data-based Mendelian randomization (SMR) method integrating summarized data of genome-wide association study (GWAS) on CCT and expression quantitative trait loci (eQTL) data to identify genes that were pleiotropically associated with CCT. We performed separate SMR analysis using CAGE eQTL data and GTEx eQTL data. SMR analysis were done for participants of European and East Asian ancestries, separately.
\end{abstract}

Results: We identified multiple genes showing pleiotropic association with CCT in the participants of European ancestry. CLIC3 (ILMN_1796423; $\mathrm{P}_{\mathrm{SMR}}=4.15 \times 10^{-12}$ ), PTGDS $\left(\right.$ ILMN_1664464; $\left.\mathrm{P}_{\mathrm{SMR}}=6.88 \times 10^{-9}\right)$ and C9orf142 $\left(\mathrm{ILMN} \_1761138 ; \mathrm{P}_{\mathrm{SMR}}=8.09 \times 10^{-9}\right)$ were the top three genes using the CAGE eQTL data, and RP11-458F8.4 $\left(\right.$ ENSG00000273142.1; $\left.\mathrm{P}_{\mathrm{SMR}}=5.89 \times 10^{-9}\right)$, LCNL1 $\left(\mathrm{ENSG00000214402.6} ; \mathrm{P}_{\mathrm{SMR}}=5.67 \times 10^{-}\right.$ $\left.{ }^{8}\right)$, and PTGDS (ENSG00000107317.7; $\left.\mathrm{P}_{\mathrm{SMR}}=1.92 \times 10^{-7}\right)$ were the top three genes using the GTEx eQTL data. No genes showed significantly pleiotropic association with CCT in the participants of East Asian ancestry after correction for multiple testing.

Conclusion: We identified several genes pleiotropically associated with CCT, some of which represented novel genes influencing CCT. Our findings provided important leads to a better understanding of the genetic factors influencing $\mathrm{CCT}$, and revealed potential therapeutic targets for the treatment of primary open-angle glaucoma and keratoconus. 
medRxiv preprint doi: https://doi.org/10.1101/2021.02.27.21252574; this version posted March 2, 2021. The copyright holder for this preprint

(which was not certified by peer review) is the author/funder, who has granted medRxiv a license to display the preprint in perpetuity.

All rights reserved. No reuse allowed without permission.

Keywords: corneal thickness; expression quantitative trait loci; summary Mendelian randomization; genome-wide association study 
medRxiv preprint doi: https://doi.org/10.1101/2021.02.27.21252574; this version posted March 2, 2021. The copyright holder for this preprint (which was not certified by peer review) is the author/funder, who has granted medRxiv a license to display the preprint in perpetuity.

All rights reserved. No reuse allowed without permission.

\section{Introduction}

The cornea is a highly collagenous and transparent tissue through which light reaches the interior structures of the eye. Previous studies highlighted the importance of central corneal thickness (CCT) in relation to several ocular and non-ocular conditions. For example, decrease in CCT is significantly associated with intraocular pressure (IOP)[1]. Thinner CCT has been demonstrated as an important feature of keratoconus and a risk factor for primary open-angle glaucoma (POAG) in patients with ocular hypertension[27]. Keratoconus is the leading cause of corneal transplants worldwide, with an estimated prevalence of $0.14 \%[8]$, while POAG is the most common cause of irreversible blindness worldwide, accounting for approximately $70 \%$ of all the cases of glaucoma[9]. Epidemiologic studies have shown that CCT differs among ethnic groups, with Europeans having higher CCT values than Africans, and Asians showing a larger variation in $\mathrm{CCT}[10]$. CCT is highly heritable, with an estimated heritability ranging from $68 \%$ to $95 \%$ [11-13]. Previous genome-wide association studies (GWAS) identified a number of CCT-associated loci in Europeans and Asians, such as genetic loci in ZNF469, FOXO1, LRRK1 and IBTK[14-20]. Recent genetic studies revealed additional novel loci associated with CCT, some of which conferred relatively high risks of keratoconus and POAG, highlighting the potential involvement of CCT-associated genes underlying the pathogenesis of keratoconus and POAG[21, 22].

Mendelian randomization (MR) uses genetic variants as the proxy to randomization and is a promising tool to explore pleotropic/potentially causal effect of an exposure (e.g., gene expression) on the outcome (e.g., CCT)[23]. MR could reduce confounding and reverse causation that are commonly encountered in traditional association studies, and 
has been successful in identifying gene expression probes or DNA methylation loci that are pleiotropically/potentially causally associated with various phenotypes, such as neuropathologies of Alzheimer's disease and severity of COVID-19[24, 25].

In this paper, we applied the summary data-based MR (SMR) method integrating summarized GWAS data for CCT and cis- eQTL (expression quantitative trait loci) data to prioritize genes that are pleiotropically/potentially causally associated with CCT.

\section{Methods}

\section{Data sources}

eQTL data

In the SMR analysis, cis-eQTL genetic variants were used as the instrumental variables (IVs) for gene expression. We performed SMR analysis using gene expression in blood due to unavailability of eQTL data for the eye. Specifically, we used the CAGE eQTL summarized data[26], which included 2,765 participants, and the V7 release of the GTEx eQTL summarized data[27], which included 338 participants. The eQTL data can be downloaded at https://cnsgenomics.com/data/SMR/\#eQTLsummarydata.

\section{GWAS data for corneal thickness}

The GWAS summarized data for CCT were provided by a recent genome-wide association meta-analysis of CCT[21]. The results were based on meta-analyses of 1000 genomes phase 1 imputed GWASs on CCT, with a total of 19 cohorts from the International Glaucoma Genetics consortium (IGGC). Specifically, the meta-analysis for participants of European ancestry included 14 cohorts with a sample of size of 17,803, and the meta-analysis for participants of Asian ancestry included 5 cohorts with a sample size of 8,107. All participating studies assumed an additive genetic model, adjusting for 
age, sex and at least the first five principal components. The GWAS summarized data can be downloaded at https://datashare.is.ed.ac.uk/handle/10283/2976. SMR analysis

We conducted the SMR analysis with cis-eQTL as the IV, gene expression as the exposure, and CCT as the outcome. The analysis was done using the method as implemented in the software SMR. Detailed information regarding the SMR method was reported in a previous publication[28]. In brief, SMR applies the principles of MR to jointly analyze GWAS and eQTL summary statistics in order to test for pleotropic association between gene expression and a trait due to a shared and potentially causal variant at a locus. We also conducted the heterogeneity in dependent instruments (HEIDI) test to evaluate the existence of linkage in the observed association. Rejection of the null hypothesis (i.e., $\left.\mathrm{P}_{\mathrm{HEIDI}}<0.05\right)$ indicates that the observed association could be due to two distinct genetic variants in high linkage disequilibrium with each other. We adopted the default settings in SMR (e.g., $\mathrm{P}_{\mathrm{eQTL}}<5 \times 10^{-8}$, minor allele frequency [MAF] $>0.01$, removing SNPs in very strong linkage disequilibrium $\left[\mathrm{LD}, \mathrm{r}^{2}>0.9\right]$ with the top associated eQTL, and removing SNPs in low LD or not in LD $\left[\mathrm{r}^{2}<0.05\right]$ with the top associated eQTL), and used false discovery rate (FDR) to adjust for multiple testing. We used Affymetrix exon array S1.0 platforms to annotate the transcripts. To functionally annotate putative transcripts, we conducted functional enrichment analysis using the functional annotation tool "Metascape" for the top 15 tagged genes[29]. Gene symbols corresponding to top hit genes were used as the input of the gene ontology (GO) and Kyoto Encyclopedia of Genes and Genomes (KEGG) enrichment analysis. 
Data cleaning and statistical/bioinformatical analysis was performed using $\mathrm{R}$ version 4.0.3 (https://www.r-project.org/), PLINK 1.9 (https://www.cog-genomics.org/plink/1.9/) and SMR (https://cnsgenomics.com/software/smr/).

\section{Results}

Basic information of the summarized data

The number of participants of the CAGE eQTL data is much larger than that of the GTEx eQTL data, so is the number of eligible probes. The sample size of the GWAS data for the European ancestry is much large than that for the Asian ancestry, so is the number of eligible genetic variants. The detailed information was shown in Table $\mathbf{1 .}$

SMR analysis in the European population

In participants with European ancestry, we identified multiple genes showing pleiotropic association with CCT after correction for multiple testing using FDR (Table 2).

Specifically, using the CAGE eQTL data, our SMR analysis identified 12 genes that were pleiotropically/potentially causally associated with CCT, with CLIC3 (ILMN_1796423; $\left.\mathrm{P}_{\mathrm{SMR}}=4.15 \times 10^{-12}\right)$, PTGDS $\left(\mathrm{ILMN} \_1664464 ; \mathrm{P}_{\mathrm{SMR}}=6.88 \times 10^{-9}\right)$ and C9orf142 $\left(\right.$ ILMN_1761138; $\left.\mathrm{P}_{\mathrm{SMR}}=8.09 \times 10^{-9}\right)$ being the top three genes $($ Figure 1). GO enrichment analysis of biological process and molecular function showed that the significant genes were involved in xxx GO terms. Concept network analysis of the identified genes revealed xxxx (Figure 2). More information could be found in Table S2.

Using the GTEx eQTL data, our SMR analysis identified six genes that were pleiotropically/potentially causally associated with CCT, with RP11-458F8.4 $\left(\right.$ ENSG00000273142.1; $\left.\mathrm{P}_{\mathrm{SMR}}=5.89 \times 10^{-9}\right)$, LCNL1 $\left(\mathrm{ENSG00000214402.6} ; \mathrm{P}_{\mathrm{SMR}}=5.67 \times 10^{-}\right.$ ${ }^{8}$ ), and PTGDS (ENSG00000107317.7; $\mathrm{P}_{\mathrm{SMR}}=1.92 \times 10^{-7}$ ) being the top three genes 
(Figure 3 \& 4). GO enrichment analysis of biological process and molecular function showed that the significant genes were involved in xxx GO terms. Concept network analysis of the identified genes revealed $\operatorname{xxxx}$ (Figure 2). More information could be found in Table Sx. It should be noted that the gene PTGDS was the top gene showing significant pleiotropic association in both SMR analyses.

\section{SMR analysis in the East Asian population}

In participants with East Asian ancestry, we identified no genes showing significant pleiotropic association with CCT after correction for multiple testing using FDR (Table 3). Specifically, using the CAGE eQTL data, we found that two genes, PASK $\left(\mathrm{ILMN} \_1754858, \mathrm{P}_{\mathrm{SMR}}=7.98 \times 10^{-5} ; \mathrm{ILMN} \_1667022, \mathrm{P}_{\mathrm{SMR}}=8.24 \times 10^{-5}\right)$ and HIATL1 $\left(\mathrm{ILMN} \_1703229, \mathrm{P}_{\mathrm{SMR}}=4.30 \times 10^{-4} ; \mathrm{ILMN} \_1737964, \mathrm{P}_{\mathrm{SMR}}=5.84 \times 10^{-4}\right)$, each of which was tagged by two probes, were among the top hits in the SMR analysis. However, none of the genes survived multiple comparison. Using the GTEx eQTL data, we found that several genes overlap with the top genes in the SMR analysis using CAGE eQTL data, including MAP7D1, HIATL1, POLA2 and ACADM. Again, none of the genes survived multiple comparison.

\section{Discussion}

In the present study, we integrated summarized data of GWAS on CCT and eQTL data in the MR analysis to explore putative genes that showed pleiotropic/potentially causal association with CCT. In the participants of European ancestry, we identified multiple genes showing significantly pleiotropic association with CCT, some of which represented novel genes associated with CCT. Our findings provided important leads to a better 
understanding of the genetic factors influencing CCT, and revealed potential therapeutic targets for the treatment of POAG and keratoconus.

We found that PTGDS (prostaglandin D2 synthase) showed significantly pleiotropic association with CCT in the participants of European ancestry using both CAGE and GTEx eQTL data. PTGDS encodes the glutathione-independent prostaglandin D2 synthase which catalyzes the conversion of prostaglandin $\mathrm{H} 2$ (PGH2) to prostaglandin D2 (PGD2), an important marker for keratocytes[30, 31]. A genetic polymorphism in PTGDS (rs11145951) was reported to be associated with CCT in the European population $\left(\mathrm{P}=9.20 \times 10^{-12}\right)$ but not in the Asian population $\left(\mathrm{P}=2.30 \times 10^{-2}\right)[15]$. The association of this polymorphism with CCT did not reach genome-wide significance in the Latino population $\left(\mathrm{P}=1.15 \times 10^{-5}\right)$, suggesting ethnic-specific effect of this genetic polymorphism[32]. PTGDS was found to be highly expressed in corneal endothelial cells (CECs)[33], ranked the among the top 50 most highly expressed genes in CECs[34]. When using a novel dual media culture approach for the in vitro expansion of primary human corneal endothelial cells (hCECs), the expression of PTGDS increased by 12.64 folds following exposure of cultivated hCECs from proliferative (M4) to maintenance (M5) medium[35]. Given that CCT was an important feature for keratoconus and a potential risk factor for POAG, these findings, together with ours, demonstrated the important role of PTGDS in influencing CCT and highlighted the potential of this gene as a promising target for the prevention and treatment of keratoconus and POAG.

RP11-458F8.4 showed the most significantly pleiotropic association with CCT using GTEx eQTL data in the participants of European ancestry (Table 2). RP11-458F8.4 is a long intergenic noncoding RNA (lincRNA). LincRNAs exercise various tissue-specific 
medRxiv preprint doi: https://doi.org/10.1101/2021.02.27.21252574; this version posted March 2, 2021. The copyright holder for this preprint (which was not certified by peer review) is the author/funder, who has granted medRxiv a license to display the preprint in perpetuity.

functions such as remodeling chromatin and genome architecture, RNA stabilization and transcription regulation[36]. $R P 11-458 F 8.4$ was reported to be associated with various types of malignant tumors. For example, it was upregulated in late stage colon cancers, and its expression may be involved in the progression of colon cancer[37]. It was found to be a prognostic lincRNA in high-grade serous epithelial ovarian cancer[38], and was differently expressed in patients with breast cancer[39]. No studies have reported the association of this gene with CCT. As a result, further investigation is needed to elucidate the exact functions of this gene and examine its role in influencing CCT.

VKORC1L1 (vitamin K epoxide reductase complex subunit 1 like 1) was pleiotropically associated with CCT in in the participants of European ancestry using CAGE eQTL data. VKORC1L1 can mediate vitamin K-dependent intracellular antioxidant functions[40]. A genetic variant in VKORC1L1 (rs11763147) was found to be associated with CCT in a combined meta-analysis of the European and the Asian samples $\left(4.0 \times 10^{-9}\right)[15]$. Another genetic variant (rs10563220) located upstream of VKORC1L1 was found to be significantly associated with intraocular pressure in a GWAS of 8,552 Chinese participants[41]. More studies are needed to elucidate the exact functions of VKORC1L1 in association with CCT, and whether/how it is involved in the pathogenesis of POAG and keratoconus.

RUNX2 (runt-related transcription factor 2) showed significantly pleiotropic association with CCT in the participants of European ancestry using the CAGE eQTL data (Table 2). RUNX2 is a member of the RUNX family of transcription factors and encodes a nuclear protein, a key transcription factor of osteoblast differentiation[42, 43]. A genetic variant in $R U N X 2$ (rs13191376) was found to be associated with CCT in a cross-ancestry GWAS 
[21]. Another genetic variant in $R U N X 2$ (rs1755056) was found to be significantly associated with IOP and weakly associated with POAG in a GWAS combing participants from the UK Biobank and published data from International Glaucoma Genetic Consortium[44]. In a transient transfection experiment using MG-63 cells and primary bovine corneal keratocytes, $R U N X 2$ transcription factors affected the expression of several small lecine rich proteoglycans (SLRP) including mimecan, biglycan and keratocan[45], which were shown to be important for the development and maintenance of corneal transparency[46-48]. In another study using the rabbit corneal epithelial cell line RCE1(5T5), RNAseq based transcriptome analysis showed RUNX2 exhibited the highest expression in terminally differentiated corneal epithelial cells[49]. In breast cancer, it was found that $R U N X 2$ functioned through the androgen receptor to regulate prolactin-induced protein (PIP)[50], a new biomarker for keratoconus[51]. These findings suggested that $R U N X 2$ likely plays an important role in affecting CCT and the susceptibility of POAG and keratoconus.

Our study has some limitations. The number of probes used in our SMR analysis was limited, especially in the SMR analysis of the participants of East Asian ancestry. As a result, we may have missed some important genes. Moreover, the sample size and the number of eligible genetic variants for GWAS in the participants of East Asian ancestry is limited, compared to GWAS in the participants of European ancestry, which may affect the power of our SMR analysis and contribute the to insignificant findings in the participants of East Asian ancestry. The HEIDI test was significant for some of the identified genes (Table 2-3). As results, the possibility of horizontal pleiotropy, i.e., the identified association might be due to two distinct genetic variants in high linkage 
disequilibrium with each other, could not be ruled out. We only used eQTL data in the blood due to the unavailability of eQTL data from the eye. Our findings need to be validated in the future when eQTL data from the eye is available.

\section{Conclusions}

We identified several genes pleiotropically associated with CCT, some of which represented novel genes influencing CCT. Our findings provided important leads to a better understanding of the genetic factors influencing CCT, and revealed potential therapeutic targets for the treatment of POAG and keratoconus.

\section{Acknowledgements}

The study was supported by Beijing Tianjin Hebei Basic Research Cooperation Project (J200006), Pharmaceutical Collaborative Innovation Research Project of Beijing Science and Technology Commission (L192062), and National Key Research and Development Project (SQ2018YFC200148). Dr. Jingyun Yang's research was supported by NIH/NIA grants P30AG10161, R01AG15819, R01AG17917, R01AG36042, U01AG61356 and 1RF1AG064312-01. Di Liu was supported by China Scholarship Council (CSC 201908110339).

\section{Author contribution}

ZY, JY and WY designed and registered the study. DL and JY analyzed data and performed data interpretation. ZY, DL and JY wrote the initial draft and JY and WY contributed writing to subsequent versions of the manuscript. All authors reviewed the study findings and read and approved the final version before submission.

\section{Availability of data and materials}

All data generated or analyzed during this study are included in this published article and its supplementary information files. 
medRxiv preprint doi: https://doi.org/10.1101/2021.02.27.21252574; this version posted March 2, 2021. The copyright holder for this preprint

(which was not certified by peer review) is the author/funder, who has granted medRxiv a license to display the preprint in perpetuity.

All rights reserved. No reuse allowed without permission.

\section{Disclosure of Potential Conflicts of Interest}

No potential conflicts of interest were disclosed by the authors. 
medRxiv preprint doi: https://doi.org/10.1101/2021.02.27.21252574; this version posted March 2, 2021. The copyright holder for this preprint (which was not certified by peer review) is the author/funder, who has granted medRxiv a license to display the preprint in perpetuity.

All rights reserved. No reuse allowed without permission.

\section{References}

1. Cho P, Lam C: Factors affecting the central corneal thickness of Hong Kong-Chinese. Curr Eye Res 1999, 18(5):368-374.

2. Cohen EJ: Keratoconus and normal-tension glaucoma: a study of the possible association with abnormal biomechanical properties as measured by corneal hysteresis (An AOS Thesis). Trans Am Ophthalmol Soc 2009, 107:282-299.

3. Gordon MO, Beiser JA, Brandt JD, Heuer DK, Higginbotham EJ, Johnson CA, Keltner JL, Miller JP, Parrish RK, 2nd, Wilson MR et al: The Ocular Hypertension Treatment Study: baseline factors that predict the onset of primary open-angle glaucoma. Arch Ophthalmol 2002, 120(6):714-720; discussion 829-730.

4. Herndon LW, Weizer JS, Stinnett SS: Central corneal thickness as a risk factor for advanced glaucoma damage. Arch Ophthalmol 2004, 122(1):17-21.

5. Kim JW, Chen PP: Central corneal pachymetry and visual field progression in patients with open-angle glaucoma. Ophthalmology 2004, 111(11):2126-2132.

6. Naderan M, Shoar S, Rezagholizadeh F, Zolfaghari M, Naderan M: Characteristics and associations of keratoconus patients. Cont Lens Anterior Eye 2015, 38(3):199-205.

7. Song C, De Moraes CG, Forchheimer I, Prata TS, Ritch R, Liebmann JM: Risk calculation variability over time in ocular hypertensive subjects. J Glaucoma 2014, 23(1):1-4.

8. Hashemi H, Heydarian S, Hooshmand E, Saatchi M, Yekta A, Aghamirsalim M, Valadkhan M, Mortazavi M, Hashemi A, Khabazkhoob M: The Prevalence and Risk Factors for Keratoconus: A Systematic Review and Meta-Analysis. Cornea 2020, 39(2):263-270.

9. Quigley HA, Broman AT: The number of people with glaucoma worldwide in $\mathbf{2 0 1 0}$ and 2020. Br J Ophthalmol 2006, 90(3):262-267.

10. Dimasi DP, Burdon KP, Craig JE: The genetics of central corneal thickness. $\mathrm{Br} J$ Ophthalmol 2010, 94(8):971-976.

11. Landers JA, Hewitt AW, Dimasi DP, Charlesworth JC, Straga T, Mills RA, Savarirayan R, Mackey DA, Burdon KP, Craig JE: Heritability of central corneal thickness in nuclear families. Invest Ophthalmol Vis Sci 2009, 50(9):4087-4090.

12. Toh T, Liew SH, MacKinnon JR, Hewitt AW, Poulsen JL, Spector TD, Gilbert CE, Craig JE, Hammond CJ, Mackey DA: Central corneal thickness is highly heritable: the twin eye studies. Invest Ophthalmol Vis Sci 2005, 46(10):3718-3722.

13. Zheng Y, Ge J, Huang G, Zhang J, Liu B, Hur YM, He M: Heritability of central corneal thickness in Chinese: the Guangzhou Twin Eye Study. Invest Ophthalmol Vis Sci 2008, 49(10):4303-4307.

14. Gao X, Gauderman WJ, Liu Y, Marjoram P, Torres M, Haritunians T, Kuo JZ, Chen YD, Allingham RR, Hauser MA et al: A genome-wide association study of central corneal thickness in Latinos. Invest Ophthalmol Vis Sci 2013, 54(4):2435-2443.

15. Lu Y, Vitart V, Burdon KP, Khor CC, Bykhovskaya Y, Mirshahi A, Hewitt AW, Koehn D, Hysi PG, Ramdas WD et al: Genome-wide association analyses identify multiple loci associated with central corneal thickness and keratoconus. Nat Genet 2013, 45(2):155163.

16. Vitart V, Bencic G, Hayward C, Skunca Herman J, Huffman J, Campbell S, Bucan K, Navarro P, Gunjaca G, Marin J et al: New loci associated with central cornea thickness include COL5A1, AKAP13 and AVGR8. Hum Mol Genet 2010, 19(21):4304-4311.

17. Cornes BK, Khor CC, Nongpiur ME, Xu L, Tay WT, Zheng Y, Lavanya R, Li Y, Wu R, Sim X et al: Identification of four novel variants that influence central corneal thickness in multi-ethnic Asian populations. Hum Mol Genet 2012, 21(2):437-445. 
medRxiv preprint doi: https://doi.org/10.1101/2021.02.27.21252574; this version posted March 2, 2021. The copyright holder for this preprint (which was not certified by peer review) is the author/funder, who has granted medRxiv a license to display the preprint in perpetuity.

All rights reserved. No reuse allowed without permission.

18. Hoehn R, Zeller T, Verhoeven VJ, Grus F, Adler M, Wolfs RC, Uitterlinden AG, Castagne R, Schillert A, Klaver CC et al: Population-based meta-analysis in Caucasians confirms association with COL5A1 and ZNF469 but not COL8A2 with central corneal thickness. Hum Genet 2012, 131(11):1783-1793.

19. Ulmer M, Li J, Yaspan BL, Ozel AB, Richards JE, Moroi SE, Hawthorne F, Budenz DL, Friedman DS, Gaasterland D et al: Genome-wide analysis of central corneal thickness in primary open-angle glaucoma cases in the NEIGHBOR and GLAUGEN consortia. Invest Ophthalmol Vis Sci 2012, 53(8):4468-4474.

20. Vithana EN, Aung T, Khor CC, Cornes BK, Tay WT, Sim X, Lavanya R, Wu R, Zheng Y, Hibberd ML et al: Collagen-related genes influence the glaucoma risk factor, central corneal thickness. Hum Mol Genet 2011, 20(4):649-658.

21. Iglesias Al, Mishra A, Vitart V, Bykhovskaya Y, Hohn R, Springelkamp H, Cuellar-Partida G, Gharahkhani P, Bailey JNC, Willoughby CE et al: Cross-ancestry genome-wide association analysis of corneal thickness strengthens link between complex and Mendelian eye diseases. Nat Commun 2018, 9(1):1864.

22. Choquet H, Melles RB, Yin J, Hoffmann TJ, Thai KK, Kvale MN, Banda Y, Hardcastle AJ, Tuft SJ, Glymour MM et al: A multiethnic genome-wide analysis of 44,039 individuals identifies 41 new loci associated with central corneal thickness. Commun Biol 2020, 3(1):301.

23. Davey Smith G, Hemani G: Mendelian randomization: genetic anchors for causal inference in epidemiological studies. Hum Mol Genet 2014, 23(R1):R89-98.

24. Liu $D$, Wang $Y$, Jing $H$, Meng $Q$, Yang J: Mendelian randomization integrating GWAS and MQTL data identified novel pleiotropic DNA methylation loci for neuropathology of Alzheimer's disease. Neurobiol Aging 2021, 97:18-27.

25. Liu D, Yang J, Feng B, Lu W, Zhao C, Li L: Mendelian randomization analysis identified genes pleiotropically associated with the risk and prognosis of COVID-19. J Infect 2020.

26. Lloyd-Jones LR, Holloway A, McRae A, Yang J, Small K, Zhao J, Zeng B, Bakshi A, Metspalu $A$, Dermitzakis $M$ et al: The Genetic Architecture of Gene Expression in Peripheral Blood. Am J Hum Genet 2017, 100(2):228-237.

27. Consortium GT, Laboratory DA, Coordinating Center -Analysis Working G, Statistical Methods groups-Analysis Working G, Enhancing Gg, Fund NIHC, Nih/Nci, Nih/Nhgri, $\mathrm{Nih} / \mathrm{Nimh}, \mathrm{Nih} / \mathrm{Nida}$ et al: Genetic effects on gene expression across human tissues. Nature 2017, 550(7675):204-213.

28. Zhu Z, Zhang F, Hu H, Bakshi A, Robinson MR, Powell JE, Montgomery GW, Goddard ME, Wray NR, Visscher PM et al: Integration of summary data from GWAS and eQTL studies predicts complex trait gene targets. Nat Genet 2016, 48(5):481-487.

29. Zhou Y, Zhou B, Pache L, Chang M, Khodabakhshi AH, Tanaseichuk O, Benner C, Chanda SK: Metascape provides a biologist-oriented resource for the analysis of systems-level datasets. Nat Commun 2019, 10(1):1523.

30. Chakravarti S, Wu F, Vij N, Roberts L, Joyce S: Microarray studies reveal macrophagelike function of stromal keratocytes in the cornea. Invest Ophthalmol Vis Sci 2004, 45(10):3475-3484.

31. Dos Santos A, Balayan A, Funderburgh ML, Ngo J, Funderburgh JL, Deng SX: Differentiation Capacity of Human Mesenchymal Stem Cells into Keratocyte Lineage. Invest Ophthalmol Vis Sci 2019, 60(8):3013-3023.

32. Gao X, Nannini DR, Corrao K, Torres M, Chen YI, Fan BJ, Wiggs JL, International Glaucoma Genetics C, Taylor KD, Gauderman WJ et al: Genome-wide association study 
medRxiv preprint doi: https://doi.org/10.1101/2021.02.27.21252574; this version posted March 2, 2021. The copyright holder for this preprint (which was not certified by peer review) is the author/funder, who has granted medRxiv a license to display the preprint in perpetuity.

All rights reserved. No reuse allowed without permission.

identifies WNT7B as a novel locus for central corneal thickness in Latinos. Hum $\mathrm{Mol}$ Genet 2016, 25(22):5035-5045.

33. Sakai R, Kinouchi T, Kawamoto S, Dana MR, Hamamoto T, Tsuru T, Okubo K, Yamagami S: Construction of human corneal endothelial cDNA library and identification of novel active genes. Invest Ophthalmol Vis Sci 2002, 43(6):1749-1756.

34. Gottsch JD, Seitzman GD, Margulies EH, Bowers AL, Michels AJ, Saha S, Jun AS, Stark WJ, Liu SH: Gene expression in donor corneal endothelium. Arch Ophthalmol 2003, 121(2):252-258.

35. Peh GS, Chng Z, Ang HP, Cheng TY, Adnan K, Seah XY, George BL, Toh KP, Tan DT, Yam GH et al: Propagation of human corneal endothelial cells: a novel dual media approach. Cell Transplant 2015, 24(2):287-304.

36. Ransohoff JD, Wei $Y$, Khavari PA: The functions and unique features of long intergenic non-coding RNA. Nat Rev Mol Cell Biol 2018, 19(3):143-157.

37. Cheng Y, Geng L, Wang K, Sun J, Xu W, Gong S, Zhu Y: Long Noncoding RNA Expression Signatures of Colon Cancer Based on the ceRNA Network and Their Prognostic Value. Dis Markers 2019, 2019:7636757.

38. Lin X, Spindler TJ, de Souza Fonseca MA, Corona RI, Seo JH, Dezem FS, Li L, Lee JM, Long HW, Sellers TA et al: Super-Enhancer-Associated LncRNA UCA1 Interacts Directly with AMOT to Activate YAP Target Genes in Epithelial Ovarian Cancer. iScience 2019, 17:242-255.

39. Xiong $\mathrm{H}, \mathrm{Chen} \mathrm{Z}$, Chen $\mathrm{W}$, Li Q, Lin B, Jia Y: FKBP-related ncRNA-mRNA axis in breast cancer. Genomics 2020, 112(6):4595-4607.

40. Westhofen P, Watzka M, Marinova M, Hass M, Kirfel G, Muller J, Bevans CG, Muller CR, Oldenburg J: Human vitamin K 2,3-epoxide reductase complex subunit 1-like 1 (VKORC1L1) mediates vitamin K-dependent intracellular antioxidant function. $J$ Biol Chem 2011, 286(17):15085-15094.

41. Huang L, Chen Y, Lin Y, Tam POS, Cheng Y, Shi Y, Gong B, Lu F, Yang J, Wang H et al: Genome-wide analysis identified 17 new loci influencing intraocular pressure in Chinese population. Sci China Life Sci 2019, 62(2):153-164.

42. van Wijnen AJ, Stein GS, Gergen JP, Groner Y, Hiebert SW, Ito Y, Liu P, Neil JC, Ohki M, Speck N: Nomenclature for Runt-related (RUNX) proteins. Oncogene 2004, 23(24):4209-4210.

43. Bruderer M, Richards RG, Alini M, Stoddart MJ: Role and regulation of RUNX2 in osteogenesis. Eur Cell Mater 2014, 28:269-286.

44. MacGregor S, Ong JS, An J, Han X, Zhou T, Siggs OM, Law MH, Souzeau E, Sharma S, Lynn DJ et al: Genome-wide association study of intraocular pressure uncovers new pathways to glaucoma. Nat Genet 2018, 50(8):1067-1071.

45. Tasheva ES, Klocke B, Conrad GW: Analysis of transcriptional regulation of the small leucine rich proteoglycans. Mol Vis 2004, 10:758-772.

46. Plaas AH, West LA, Thonar EJ, Karcioglu ZA, Smith CJ, Klintworth GK, Hascall VC: Altered fine structures of corneal and skeletal keratan sulfate and chondroitin/dermatan sulfate in macular corneal dystrophy. J Biol Chem 2001, 276(43):39788-39796.

47. Tanihara H, Inatani M, Koga T, Yano T, Kimura A: Proteoglycans in the eye. Cornea 2002, 21(7 Suppl):S62-69.

48. Podskochy $\mathrm{A}$, Koulikovska $\mathrm{M}$, Fagerholm $\mathrm{P}$, van der Ploeg I: Biglycan gene expression in UVR-exposed rabbit corneas. Acta Ophthalmol Scand 2004, 82(2):200-204. 
medRxiv preprint doi: https://doi.org/10.1101/2021.02.27.21252574; this version posted March 2, 2021. The copyright holder for this preprint (which was not certified by peer review) is the author/funder, who has granted medRxiv a license to display the preprint in perpetuity.

All rights reserved. No reuse allowed without permission.

49. Ortiz-Melo MT, Garcia-Murillo MJ, Salazar-Rojas VM, Campos JE, Castro-Munozledo F: Transcriptional profiles along cell programming into corneal epithelial differentiation. Exp Eye Res 2021, 202:108302.

50. Naderi A: Prolactin-induced protein in breast cancer. Adv Exp Med Biol 2015, 846:189200.

51. Sharif R, Bak-Nielsen S, Hjortdal J, Karamichos D: Pathogenesis of Keratoconus: The intriguing therapeutic potential of Prolactin-inducible protein. Prog Retin Eye Res 2018, 67:150-167. 


\section{Figure Legends}

Figure 1. Prioritizing gene around $C L I C 3, P T G D S$ and $C 90 r f 142$ in pleiotropic association with CCT in the participants of European ancestry using CAGE eQTL data.

Top plot, grey dots represent the $-\log _{10}(P$ values $)$ for SNPs from the GWAS of CCT, and rhombuses represent the $-\log _{10}(P$ values $)$ for probes from the SMR test with solid rhombuses indicating that the probes pass HEIDI test and hollow rhombuses indicating that the probes do not pass the HEIDI test. Middle plot, eQTL results. Bottom plot, location of genes tagged by the probes.

CCT, central corneal thickness; GWAS, genome-wide association studies; SMR, summary data-based Mendelian randomization; HEIDI, heterogeneity in dependent instruments; eQTL, expression quantitative trait loci

Figure 2. Prioritizing gene around $R P 11-458 F 8.4$ in pleiotropic association with CCT in the participants of European ancestry using GTEx eQTL data.

Top plot, grey dots represent the $-\log _{10}(P$ values $)$ for SNPs from the GWAS of CCT, and rhombuses represent the $-\log _{10}(P$ values $)$ for probes from the SMR test with hollow rhombuses indicating that the probes do not pass the HEIDI test. Middle plot, eQTL results. Bottom plot, location of genes tagged by the probes.

CCT, central corneal thickness; GWAS, genome-wide association studies; SMR, summary data-based Mendelian randomization; HEIDI, heterogeneity in dependent instruments; eQTL, expression quantitative trait loci 
Figure 3. Prioritizing gene around $L C N L 1$ and $P T G D S$ in pleiotropic association with CCT in the participants of European ancestry using CAGE eQTL data.

Top plot, grey dots represent the $-\log _{10}(P$ values $)$ for SNPs from the GWAS of CCT, and rhombuses represent the $-\log _{10}(P$ values $)$ for probes from the SMR test with solid rhombuses indicating that the probes pass HEIDI test and hollow rhombuses indicating that the probes do not pass the HEIDI test. Middle plot, eQTL results. Bottom plot, location of genes tagged by the probes.

CCT, central corneal thickness; GWAS, genome-wide association studies; SMR, summary data-based Mendelian randomization; HEIDI, heterogeneity in dependent instruments; eQTL, expression quantitative trait loci 


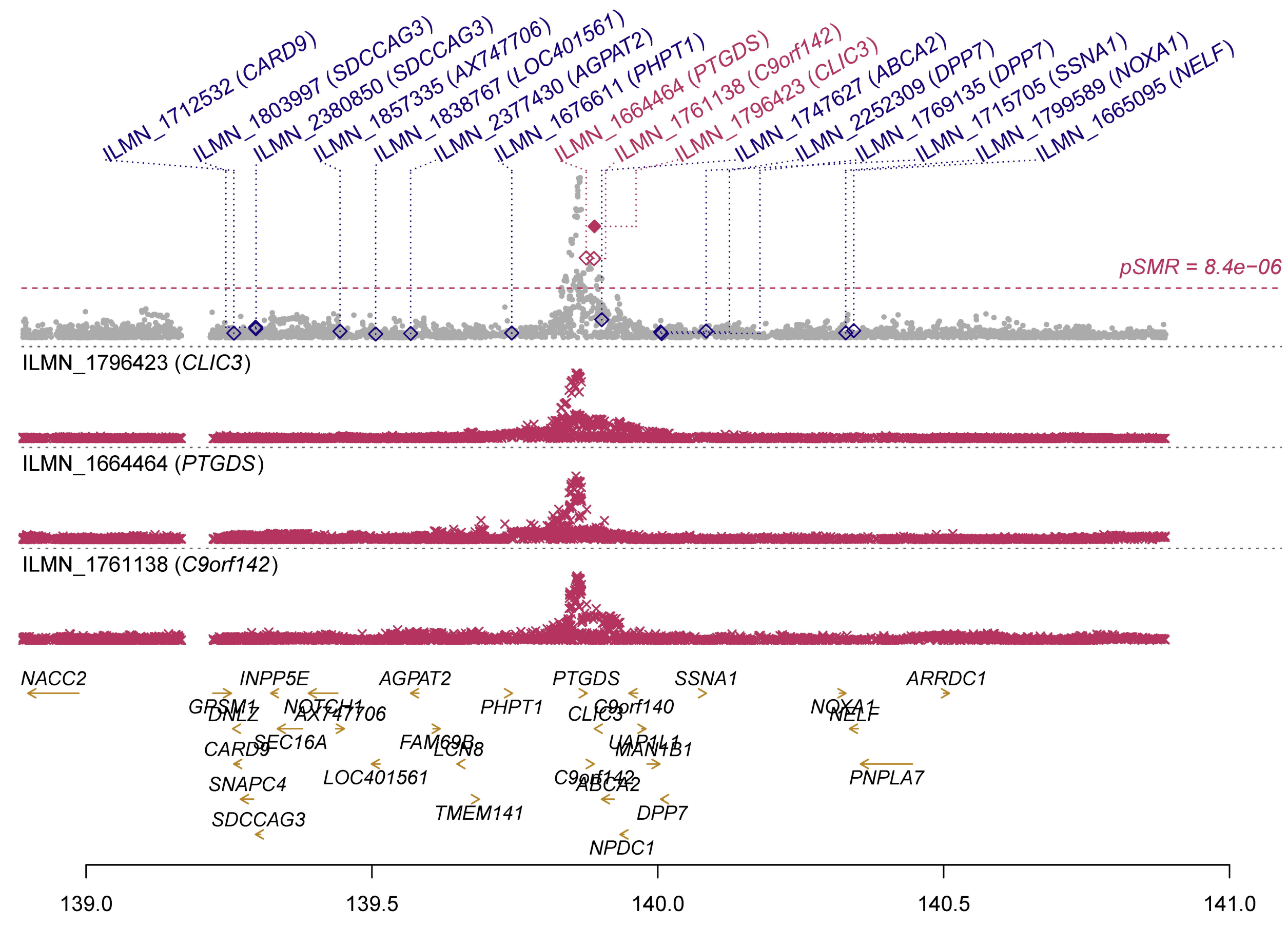

Chromosome $9 \mathrm{Mb}$ 


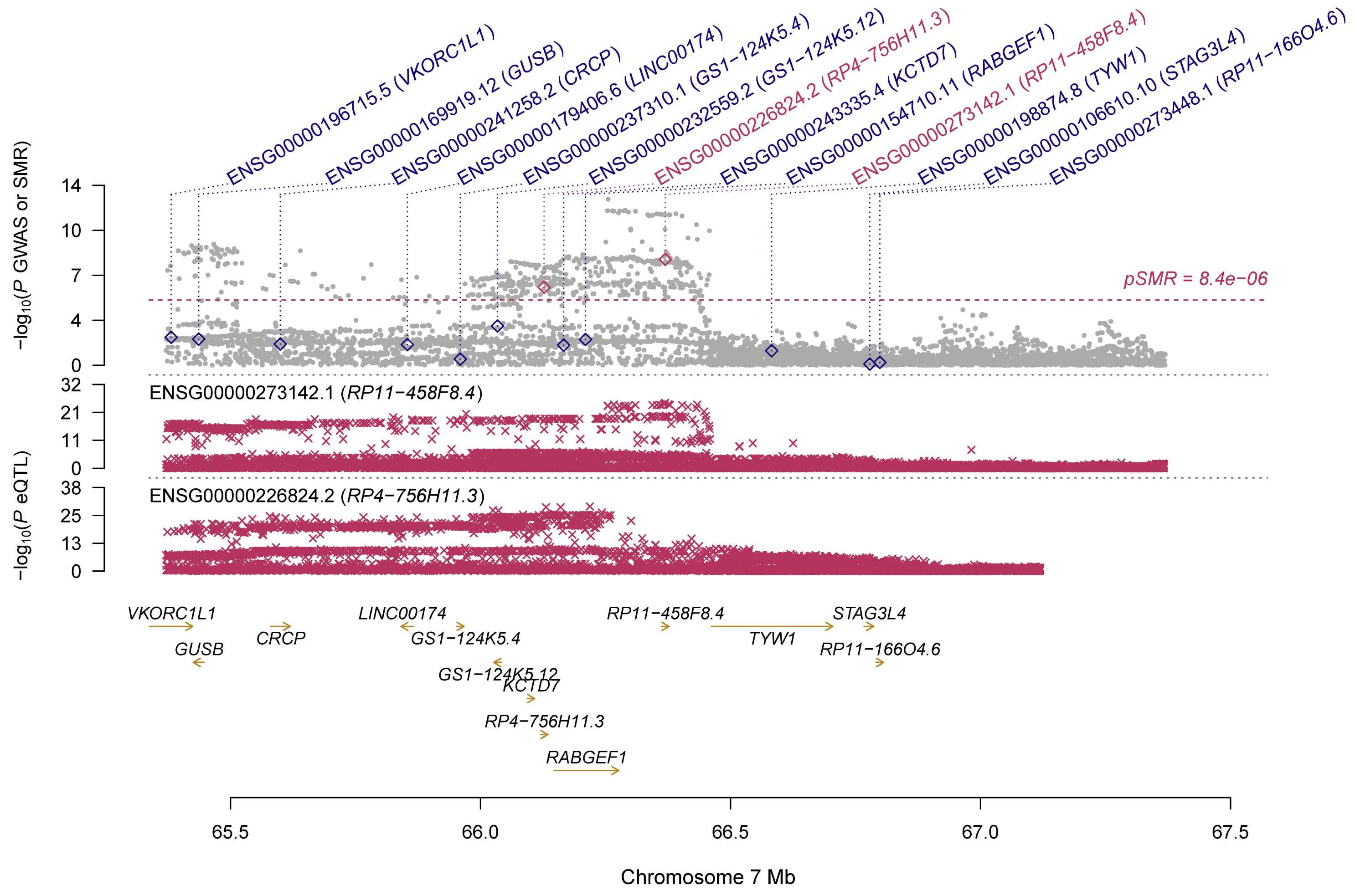




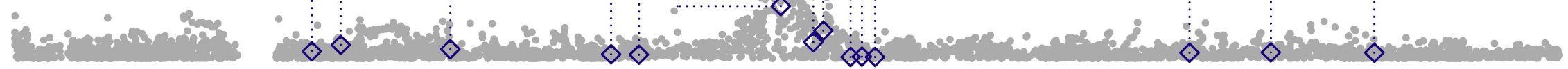

0

17

\section{ENSG00000214402.6 (LCNL1)}

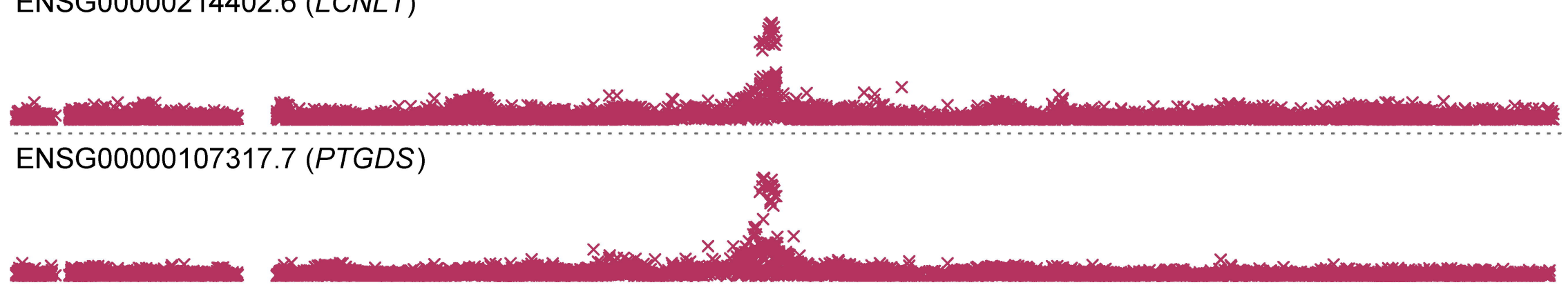

\begin{tabular}{|c|c|c|}
\hline \multicolumn{2}{|c|}{ DNLZ RP11-611D20.2 } & PTGDS \\
\hline CARDEC16A & FAM $69 B$ & LCNLPDC1 \\
\hline SNAPC4 & SNHGT & 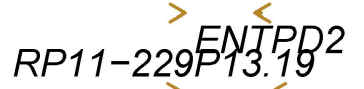 \\
\hline SDCC\&AG3 & $\begin{array}{c}\text { LCN8 } \\
\text { TMEN }\end{array}$ & 141 \\
\hline
\end{tabular}

\section{NOXA1 $\underset{\gg}{\not} \quad$ RRDC1 \\ PNPLA7 EHMT1}

